\title{
Transnational policy and 'authenticity' discourses on Romani language and identity
}

\author{
Y A R O N M A T R A S \\ School of Arts, Languages and Cultures University of Manchester \\ Oxford Road, M13 9PL, UK \\ yaron.matras@manchester.ac.uk
}

\section{A B S T R A C T}

\begin{abstract}
Romani is a fascinating test case for the role that language plays in the process of identity consolidation in a transnational context. Standardisation is no longer inherently connected to the 'territorialisation' of language. Instead, we witness a bottom-up process in which individuals take ownership of language and negotiate language practices. Status regulation and language planning can be instigated and even implemented by institutions other than national states. All of this leads to pluralism of form rather than unification. Yet language remains a key locus for political mobilisation. It allows players to claim authenticity, it offers opportunities for intervention by external facilitators, and it provides a discussion platform through which traditional images can be challenged and recognition can be awarded. (Romani, language planning, standardization, language policy, transnationalism)*
\end{abstract}

\section{N T R O D U C T I O N}

The Romani people occupy a distinct and rather exceptional position as an ethnic minority in Europe: They are geographically dispersed and have no territorial centre or 'home region'. They suffer considerable social stigma and marginalisation. Their social organisation traditionally revolves around kinship structures and networks of families; in the absence of community institutions, political expression of Romani identity is a fairly recent phenomenon. What precisely constitutes Romani 'identity' is therefore subject to much debate at various levels. Popular perception has tended to view Romani culture as a chosen or inherited 'lifestyle' rather than 'ethnicity'. This view is partly reinforced by the pre-occupation in the social sciences with so-called 'peripatetic cultures', that is, populations that rely on a mobile service economy, which anthropologists have often regarded as the principal characteristic feature of Romani society. Such perception is also reflected in the tendency of governments and international organisations such as the Council of Europe and the European Union to use 'Roma' as a so-called 'umbrella term' that denotes populations of diverse ethnic and linguistic backgrounds (cf. Matras 2013). 
In the present article I examine the role of the Romani language in defining Romani identity in contemporary transnational political discussions. I give attention to three dimensions. I begin with a brief summary review of emerging practices that lead to an expansion of usage domains in Romani. A language that was until recently reserved for oral, face-to-face communication in familiar contexts is now expanding into printed media and electronic communication in websites and social media. Here, Romani serves as a binding factor for individuals of different geographical and family network backgrounds - as a kind of bottom-up, transnational vehicle of communication and as an expression of identity. In this context, little or no effort is made to standardise or unify language usage either in written or oral form. Instead, participants engage in a decentralised and organic process of exchange that features pluralism of linguistic forms and structures. Next, I discuss the attention given to the Romani language as part of the transnational political process at the European level (the European Union, Council of Europe and affiliated agencies). The pre-occupation with language in this context is testimony to the way in which language policy serves as a means of granting recognition to a transnational Romani identity at the institutional level. Lately, this has become characterised by a move away from traditional models of unification that normally accompany the process of institutional recognition of language. Instead, notions of pluralism are embraced. Finally, I show how these developments - the emergence of Romani literacy as a binding element among dispersed communities and individuals, and the recognition granted to the Romani language and so to Romani identity at institutional level - are seen as an opportunity by individual Romani activists to influence images and perception of the Roma. Activists put forward their own views on language in order to gain authority and mobilise support for their political cause. Mimicking the style of historical-linguistic analyses, they use language to construct a Romani identity. In order to lend their narrative credibility and authority they present their own pre-occupation with language as authentic, that is, as deriving, supposedly, from their own experiences as members of the Romani community.

All three dimensions - the use of the Romani language to express identity, reference to the Romani language as a way of granting recognition to Romani identity, and pre-occupation with the Romani language as a way of constructing identityare anchored in the reality of territorial dispersion and the absence of territorial sovereignty, and lately also of linguistic pluralism, all of which are untypical of the process of language formation in conjunction with emerging national identities. In this regard, the Romani case study offers an example of a paradigm shift.

This paradigm shift can be recognised at two separate levels (see also discussion in the following section). First, the promotion of Romani as a way of protecting the human rights of its speakers is not aligned to the usual model for 'standardisation', which involves the creation of a homogenous community of communication. Second, the Romani case is exceptional because due to the absence of any Romani claims to territorial sovereignty the link between language and nationalism is not obvious. Consequently, the instruments that serve the process of language 
policy are distinct, and rely primarily on the engagement of a loose network of nongovernmental organisations and individual activists with transnational organisations of governance, each of which has limited powers to implement writtenlanguage norms or even to support language-promotion activities at local level.

A key objective of standardisation is to achieve a degree of uniformity in language, which in turn stands for similarities among individual user populations and thus for the essence of a shared identity (Edwards 2006:19). The notion of 'linguistic human rights' (Skutnabb-Kangas \& Phillipson 1994) is based on accepting this premise. While the principle of language rights is, as Wright (2004:183 ff.) acknowledges - supported by the discourses of liberty, fraternity, equality, and justice - it is also anchored in the assumption that explicit institutional recognition at a higher level is a necessary prerequisite for the legitimacy of ideological claims to nationhood or ethnic identity. What we find in Romani blurs these connections in the following way: The Romani 'nationalist' discourse is not one that seeks to establish territorial sovereignty but rather one that seeks to forge active links between Romani communities that are dispersed in different countries. The Romani human rights discourse, in turn, seeks acknowledgement from public institutions of the existence of a Romani identity that is manifested through different cultural practices in different places. To these ends, Romani activists have turned to the political process at the European level for recognition and support, and to bottom-up and decentralised initiatives for the actual process of extending and expanding domains of language use. As a result, the Romani case differs from conventional standardisation in that it shows an effort to forge a shared identity by relying on the symbolic support of transnational organisations of governance and on embracing pluralism of forms.

\section{THE ROMANI CASE AS A 'PARADIGM SHIFT'}

The power of language to act as an identity symbol draws on its function as an emblem of individuals' loyalty to peer groups and so as a way of flagging and shaping social and ethnic-national identity (cf. Giles \& Johnson 1987; Baker 1992; Eckert 2003; Fought 2006). Research interest in institutional efforts to plan and regulate language use was first prompted by attempts to capitalise on this symbolic and identity-forming role of language in the context of postcolonial nationstate building (cf. Fishman, Ferguson, \& Dasgupta 1968). Language planning has since been understood as deliberate, future-oriented action that aims to change (certain aspects of) the formal system of language and modify the linguistic behaviour of members of a community. Intervention is normally regarded as a form of management of linguistic practices that is guided by ideological beliefs (cf. Kaplan \& Baldauf 1997; Spolsky 2003). Standardisation, including regulation of form and status, is seen as an act that provides institutional legitimacy to language varieties (Milroy 2001) and that can help provide legitimacy to a claim for nationhood (cf. Jaffe 1999; Joseph 2004). 
But language may also take on performative functions (cf. Joseph 2004). Efforts to support, promote, or safeguard a minority language, especially an endangered minority language, can serve as a social and political weapon against colonial rule (cf. Crowley 2007). Postcolonial theory has therefore not surprisingly developed a framework for a critical approach to the interrelation between public language and ideological power (see Fairclough 1989; Crowley 2003). In this context, discourse itself is seen as the site of ideology, and language is regarded as one of several identity-building resources (Blommaert 2005). The principle of uniformity is in turn substituted or at least weakened considerably by an acceptance of pluralism. Wright (2004:96-98) describes how language planning was inherently associated with an ideology of nationalism. As part of nation building, state institutions took on the role of regulator of linguistic form, sponsoring the drafting and implementation of a unified linguistic standard in written and often also in oral usage. Language planning was thus inherently associated with tight regulation and unification of form and linguistic practice. But with changing ideologies, the idea of regulating language has become less acceptable. Instead, the paradigm shift that is influenced by postmodernist and postnational thinking lends support to diversity and pluralism.

This critical approach to the role of language in nationalist ideology is strongly inspired by Anderson's (1983) argument that nationalism revolves around the construction of 'imagined communities'. Anderson attributes a key part in the emergence of nationalist discourses to linguistic practices and specifically to the emergence of literary versions of vernacular languages. As late medieval European elites began using their idiolects in correspondence, they removed the traditional association between script and global religious ideology that was represented by Latin (as well as Old Church Slavonic and Greek). The invention of print enabled the spread of scripted vernaculars to wider regions and the emergence of codified varieties that became widely understood by users of related dialects, giving rise to 'territorial' languages. These were then imposed top-down as part of the ideological edifice of emerging nation-states, from the nineteenth century onwards. In Anderson's narrative, functionality and convenience of communication thus precede the symbolic, unifying effect of language codification. At the same time, 'territorialisation' of language plays a key role both in language standardisation and in the process of nation building, which it serves.

Joseph (2004) points to the role of individuals in the process when he mentions that national languages start off as the product of intellectuals and only become a widespread ideology and a national property once they enter the education sphere, facilitated by state institutions. In the absence of state institutions that can promote a national language, efforts to instigate widespread change in language usage must rely on the persuasive power of individual language activists. Such initiatives by individuals have been described for a number of cases. They include those of Eliezer Ben-Yehuda for Hebrew (Kuzar 2001), whose work began in eastern Europe long before the emergence of a territorially based Hebrew-speaking 
community in Palestine; of Ziya Göklap for Turkish after the emergence of the modern Turkish Republic (Aydıngün \& Aydıngün 2004); and as described in Matras \& Reershemius (1991) of Nathan Birnbaum for Yiddish, which, like Romani, lacks a territorial base, and of Celadet Ali Bedir-Xan for Kurmanji Kurdish, spoken across the national boundaries of several states in the Middle East as well as in European diaspora communities.

Romani represents an exceptional case of language planning and language policy-making at a transnational level: Instigated by a noncentralised network of activists seeking to challenge popular images of 'Gypsies', it seeks recognition primarily from European-level policy institutions. This has unusual implications for the recognition at institutional levels of diversity in language, rather than striving for uniformity as is usually the case. In this respect, Romani offers a notable case of a paradigm shift. In the absence of a state or territorial coherence, public use of the Romani language serves to flag individuals' loyalty to a transnational collective. Codification and the promotion of Romani in new functions is a decentralised and pluralistic process, and institution-driven language engineering and regulation and unification attempts are marginal. The agents who promote the language are in all but a few cases individuals who draw on a range of international networking opportunities. Only in some cases do they benefit from the support of governments at national and local levels. Yet despite the absence of centralisation and territorialisation, the promotion of Romani is a key element in the consolidation and politicisation of Romani identity, and language serves as a key argument in attempts to legitimise demands for Romani political representation and for protection from discrimination and exclusion.

In this context, language has an argumentative value. Social inclusion is seen by many in the activist scene, but also among officials in European institutions, as predicated on protection from discrimination and on some form of political participation and self-representation. This in turn requires a change in attitudes toward the target population. Flagging the linguistic coherence of the Romani populations is regarded as a key argumentative tool toward revising traditional images of 'Gypsies' as a lifestyle or a social grouping and replacing them with an acknowledgement that the Romani population constitutes an ethnic minority. Political resolutions that recognise the right for education in Romani and the need to make provisions to safeguard and promote the language can be taken as recognition of Romani ethnicity and by inference of the legitimacy of structured Romani political participation. The historical narrative that surrounds the Romani language (see Matras 2002) also offers a way to overcome the problem of recognising the dispersed Romani populations as a single ethnic minority, by relating Romani identity to an historical territory of origin in India. However void this historical relationship is of any practical implications in terms of present-day policy, from the activist perspective it lends plausibility to the concept of Romani ethnicity, and so it lends legitimacy to the demand for political representation and protection from racism and discrimination (cf. Hughes 2013). 
Based on this link between language and the discourse of emancipation, the preoccupation with the Romani language becomes in itself an act of empowerment at various different levels. The demand for formal recognition of the Romani language constitutes effectively a demand for political recognition. The act of publishing in Romani, designing a writing system (codifying) and promoting consistency in its use (standardising), and supporting the use of the language in new domains, especially in public and institutional settings, constitutes a political act that symbolises aspirations for political recognition and participation. Many activists see networking and rallying around language as an integral part of the process of nation building. This is also true for the construction of historiographical narratives that draw on the symbolism of language and purportedly also on linguistic evidence, and which aim to promote self-confidence among Romani activists to claim ownership over the dissemination of images and interpretation of Romani history. The availability of resources to support Romani language print and websites has provided activists with opportunities and with a material motivation to engage in language promotion activities. Language is thus a platform for debate on images, perception, and the status of the Romani people, one through which roles and relationships among agents/players, facilitators, and audiences can be negotiated.

\section{OMAIN EXPANSION IN ROMANI: EMERGING P R A C T I C E S}

Written use of Romani began, aside from research-oriented documentation, with the publication of Gospel translations by missionaries in the late 1800s. This was followed by state-sponsored literacy in the Soviet Union for a short period between 1928-1936. Romani writing then took on pace during the late 1960s and early 1970s, when private individuals and cultural associations, sometimes backed by government institutions, initiated the publication of Romani grammars and dictionaries as well as newsletters in various countries including Finland, Sweden, Macedonia, Czechoslovakia, and Hungary. The model for codification set during this period was based on the selection of the principal local or regional Romani dialect and a writing system based on that of the national language, often with some modifications such as diacritic symbols for particular sounds. This model laid the foundations for a strategy that proliferated after the fall of Communism and the expansion of Romani cultural activities in central and eastern Europe, and of transnational networking (see Matras 1999, 2005a, 2005b; Halwachs 2011).

The outcome has been a plethora of diverse and decentralised codification initiatives. Their 'agents' are usually Romani activists who are involved in political and human rights campaigns alongside cultural and literary activities. They are sponsored by 'facilitators', some of whom are governments and academic institutions. Much support for Romani literacy in the period after 1990 has come from the European Union's PHARE programme and George Soros's Open Society 
Institute. A spin-off project of the Open Society Institute's Information Program, the Next Page Foundation, awarded grants specifically for the promotion of Romani literacy. Between 2002-2007 it funded the production of Romani language print publications and web publications produced by altogether thirty organisations in twelve central and eastern European countries. The texts included collections of folk tales, biographies, and educational material. ${ }^{1}$ The foundation's explicit policy was not to impose any codification standards but to take a pluralistic approach to the choice of dialect and orthographic variants. Between 2001-2007, Next Page and the Open Society Institute also supported work carried out at the universities of Graz and Manchester toward the production of an online, multidialectal Romani language dictionary—-Romlex. ${ }^{2}$ This resource, too, takes the pluralism approach by capturing dialect variants from more than twenty-five different Romani varieties. Romlex has become one of the most popular Romani language resources, with the number of annual queries rising steadily from around 25,000 in 2009 to over 41,000 in 2013, high numbers coming from Austria, the Czech Republic, France, Germany, Spain, Sweden, the United Kingdom, and the United States.

By the mid 1990s the expansion of Romani into the virtual world became the principal stage for Romani literacy (cf. Halwachs 2011, 2012; Leggio 2013). It drew on the reality that Romani had become both a practical and a symbolic communication vehicle among the growing international networks of Romani activists. Regular international meeting forums, many of them sponsored by multilateral organisations such as the Council of Europe and the CSCE/OSCE in the early 1990s, offered a platform for political exchange. Romani was the natural lingua franca among the delegates who originated in different countries, mainly from central and eastern Europe. The practice of pluricentric or country-bound codification continued in electronic communication, as did in many cases that of pluralism of form - in choice of both dialect features and orthography - even within one and the same platform. Swedish state radio (Sveriges Radio), for example, maintains a Romani language website (Radio Romano) with daily updates of Romani language news reports, available both in written form and as audio streaming. The explicit policy is to mix dialects and orthographic variants and one consequently finds side by side on the same page dialectal variants such as adjes and avdive 'today', shunen and ashunen 'they hear', kado and akava 'this'; inconsistencies in the values of orthographic symbols, as in jekh /jek/ 'one' but juvlia /dzuvlja/ 'women'; and different ways of spelling the same sounds, as in politsia 'police' but procento/protsento/ 'percent', aratchi/aratfi/ 'yesterday' but chavore /tfavore/ 'children'. ${ }^{3}$

Romani language websites tend toward greater consistency in form by comparison to other online media, since they are usually run by a small group of authors. But the main popularisation of Romani language literacy and public communication is connected to the expansion of social media from around 2003-2004 onwards. Many virtual spaces serve to connect people around their Romani cultural 
and family identity without explicitly rallying around shared political-ideological content. The use of Romani is not prescribed and is often not required to support communication among participants, yet it allows them to flag a sense of common heritage and destiny and thus to nourish an emotional attachment to one another. Online Romani chats extend to Romani-speaking communities such as that of the Sinti in Germany and neighbouring regions, where political activists are generally reluctant to promote the use of Romani in public. The 'Sinti Chat' portal, for example, contains welcoming phrases in both German and Sinti Romani and participants code-switch both within and across turns, resorting to an improvised writing system for Romani (and for colloquial German) based by and large on German orthographic conventions:

(1) Sinti Chat (http://www.zigeuner.de/01_sinti-chat.htm), February 22, 2010

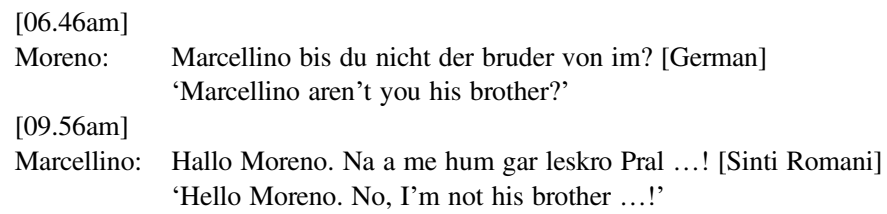

Similarly, Leggio (2013) describes how users in one particular online Romani chat forum make use of 'cosmopolitan practices'. Centred around Romani Balkan music, Radio Mahalla ${ }^{4}$ is operated by a group of DJs and attracts primarily young Roma based in various western European countries (Germany, France, Italy) whose families originate in the Romani community of Mitrovica in Kosovo. Users employ a mixture of languages but the use of Romani is what flags and indeed constructs a shared diasporic identity.

A corpus of Romani-language comments posted on YouTube videos (Leggio \& Matras 2013) shows how the language has become a frequent and often default choice for users reacting to Romani content uploaded by private individuals. Videos with religious content often attract comments by users of a variety of backgrounds, as seen in the pluralism of choices of dialect forms and spelling. By contrast, music and family events show a strong tendency toward dialect coherence. They represent user networks that tend to belong to the same Romani community, speaking the same or a very similar dialect and usually originating in the same region. Nonetheless, even among these groups users appear to be geographically dispersed, as suggested by the choice of different spelling conventions triggered by exposure to different contact languages. The mixture of forms and spelling conventions indicates how the virtual space serves as an organic transnational network through which a shared Romani cultural identity is celebrated via the medium of a shared language.

We can thus recognise a Romani 'virtual community' (in the sense of Rheingold 1993 and Herring 2008). It is a community that tends to make use of the flexibility 
offered by the informal character of social media to transpose everyday multilingual practices such as code-switching from face-to-face, private and oral communication into remotely relayed, public communication in writing (cf. Androutsopoulos 2013) and one that at the same time uses the opportunities offered by the electronically mediated communication to promote a written form for a speech variety that has so far been limited to vernacular use (cf. Rajah-Carrim 2009). Online social media represent a new domain of language use, one that relies on basic literacy skills and so on a bottom-up codification of language without either a regulatory norm or any form of territorialisation. They show how pluralism of form can exist side-by-side with community-specific dialect choices. In social media and online newsletters, agents do not require facilitators for individual contributions as long as they have access to the technical facilities such as Yahoo lists, chat platforms, and open forums like YouTube, while dissemination to audiences is not an issue thanks to the blurring of any clear-cut distinctions between agents and audiences.

\section{LANGUAGE PLANNING ATA TRANSNATIONAL LEVEL}

Co-existing with this bottom-up, decentralised and organic process of literacy emergence in Romani are political efforts to grant recognition to the Romani language at the European level. The Council of Europe's first statement on the Romani language dates back to 1981, when its Standing Conference of Local and Regional Authorities adopted Resolution 125 on the 'Role and responsibility of local and regional authorities in regard to the cultural and social problems of populations of nomadic origin', calling on member states to grant them 'the same status and advantages as other minorities enjoy, in particular concerning respect and support for their own culture and language'. In 1983, the Council of Cultural Co-operation recommended that 'the Romany language and culture be used and accorded the same respect as regional languages and cultures and those of other minorities', speaking explicitly of 'Romani', but in 1989, the Council of Ministers of Education voted to promote teaching materials that 'give consideration for the history, culture and language of Gypsies and Travellers'. These declarations were the product of lobbying activities by Romani intellectuals and their supporters, often academics with an interest in Romani studies.

The protection and promotion of Romani identity and culture became a highly pertinent issue on the agenda of European institutions after 1990, with the realisation that immigration of Roma from countries such as Romania, Poland, Slovakia, and former Yugoslavia into western Europe was triggered in part at least by racial discrimination and social marginalisation in the postcommunist countries. As part of the enlargement of the European Union, pressure was put on the new accession countries to secure an accepted level of human rights standards. Arguably, interest in protecting Romani culture was driven by an interest among western European governments to prevent large-scale migration of eastern European Roma to the 
West (cf. Matras 2013). In 1992, Josephine Verspaget, a member of the Council of Europe's Parliamentary Assembly, tabled a report that formed the basis of the Parliamentary Assembly's Recommendation 1203 'On Gypsies in Europe'. The report followed media attention to a rise in violent attacks and police brutality against Romani settlements and individuals in central and eastern Europe, and public campaigns against the expulsion of Romani asylum-seekers from those countries where they sought refuge, such as Germany and the Netherlands. Verspaget was advised by the Dutch Lau Mazirel Foundation, which had close links to the Romani community in the Netherlands as well as to the Roma National Congress, an NGO based in Hamburg, Germany, which led many of those campaigns. Recommendation 1203 was considered a significant breakthrough in that it called for the first time for a permanent Romani political representation at the European level. It also acknowledged language as a key element of Romani culture and thus a key to the protection of Romani identity, calling for the establishment of 'a European programme for the study of Romanes 5 and a translation bureau specialising in the language', and recommending that 'the provisions for non-territorial languages as set out in the European Charter for Regional or Minority Languages should be applied to Gypsy minorities'.

Subsequent resolutions continued to emphasise the link between political participation, social inclusion, and promotion of the Romani language. In February 2000, the Council of Europe's Committee of Ministers in its Recommendation 2000/4 'On the education of Roma/Gypsy children in Europe' stated that 'in countries where the Romani language is spoken, opportunities to learn in the mother tongue should be offered at school to Roma/Gypsy children', and that 'the participation of representatives of the Roma/Gypsy community should be encouraged in the development of teaching material on the history, culture or language of the Roma/Gypsies'. By 2000 at the latest, a consistent position had been established within the Council of Europe, recognising a coherent language (called variably Romani, Romany, or Romanes), and recognising the need to give it consideration especially within the education system. Implicitly, despite continuing resolutions that address the needs of 'Gypsies and Travellers' or of 'people of nomadic origin', this direction of statements also granted recognition to the Romani minority as a linguistic minority in Europe and so to Romani as the symbolic expression of collective identity.

Other European political texts have at times taken a much more practical approach to Romani, viewing it as an instrument that can facilitate access to services and so a key to integration rather than a token of political-ethnic particularity. The European Commission's European Anti-Discrimination Law Review 6/7 (2008) states that 'Measures aimed at women from majority groups do not service Roma women, because they do not take into account Roma language and culture'. ${ }^{6}$ The Council of Europe's European Monitoring Centre on Racism and Xenophobia states in a text on health care for women, published in 2003: 'Provision should 
be made for use of the Romani language to improve prevention and attain optimal care'. ${ }^{7}$

Nonetheless, the Romani experience provides an interesting example of an emerging language-planning and language-policy process at the transnational level. The Council of Europe continued to take a direct interest in the practical promotion of Romani language teaching. It initiated a series of expert consultations and in publications arising from these meetings it called on state governments to increase awareness of the Romani language in the school context ${ }^{8}$ and to help Roma pupils overcome social barriers by communicating with them in Romani. ${ }^{9}$ After being lobbied for over a decade and a half by a circle of activists to lend its support to a project on the standardisation of Romani, the Council of Europe changed direction in 2005, handing over the issue from the Directorate of Education to the Language Policy Division. A report commissioned by the Language Policy Division (Matras 2005a) recommended support for the prevailing trend toward pluralism of form and structure in Romani language publications and teaching. The Language Policy Division carried this approach forward to another Council of Europe body, the Committee of Experts that oversees the European Charter for Regional or Minority Languages. A document arising from a joint hearing with the Committee in late 2005 mentions the role of European institutions in helping produce teaching and learning materials that could then be adapted to local needs and local dialects. ${ }^{10}$ It also states that standardisation is not a demand and that the absence of a standard should not be a reason not to improve Romani language educational facilities. ${ }^{11}$ Representatives of the European Roma and Traveller Forum (ERTF), a Romani NGO with consultative status at the Council of Europe, also attended the hearing. In the aftermath, the ERTF published a policy paper on the Romani language, in which it stated:

The Romani language must be recognized as a language, according to the Charter for Regional and Minority Languages, in every member state. It must be allocated a position in the national curriculum and afforded an appropriate budget. The lack of an internationally recognized 'standard dialect' is not a barrier to a state's implementation of rights related to language use and learning. ... The goal of teaching Romani language is not only to enable a student to speak one dialect well but also to understand and have some knowledge of the Romani used by others across Europe. While a standard dialect is not needed, mutual comprehension and 'linguistic pluralism' are essential. ${ }^{12}$

Taking the process further, the Language Policy Division invited an expert group to consult on the creation of a European Curriculum Framework for Romani (CFR), modelled on previous documents created for a number of other languages. The CFR $^{13}$ was published in 2008 and contains an outline of culture-specific communicative tasks to be considered in the development of teaching and learning materials, including 'the home/caravan', 'Roma crafts and occupations', 'festivals and celebrations', 'food and clothes', 'transport and travel', and more. Two implementation projects, both funded by the European Commission's Lifelong Learning Programme in the form of a consortium of partner institutions from different countries, have since worked toward the creation of online teaching and learning 
materials for Romani based on the CFR: RomaniNet (2009-2012),${ }^{14}$ which produced an online animated integral Romani language course, and QualiRom (2011-2013), which produced teaching materials and teacher training packs in six different dialects of Romani for use in primary and secondary schools. ${ }^{15}$ These efforts, coordinated and funded at European level, lay important foundations for states to be able to implement calls for the promotion of Romani. Since the Council of Europe's interest in the topic began, the European Parliament has called for practical measures such as 'increasing the number of Roma teachers and ensuring the protection of the language and identity of Roma children by making education available in their own language', ${ }^{16}$ and other European bodies have called on member states to 'offer Roma pupils instruction in their mother tongue, upon parents' request'. ${ }^{17}$ In the European Charter for Regional or Minority Languages (ECRML) of 1992, Romani ('Romany') is mentioned explicitly as an example of a nonterritorial language, to which some parts of the Charter may be applied. Since then, some fifteen states have recognised Romani as a minority language within the Framework of the Charter. The Charter divides its catalogue of provisions into two categories. States undertake to apply Part II provisions to languages that they list under the Charter. Part II covers general principles such as raising awareness including the promotion of research and teaching and learning opportunities and the elimination of any restrictions on the language. Part III covers specific measures to promote the minority language in public life. States are obliged to select a certain number of provisions from Part III, some of those from designated sections.

Most states limit the recognition granted to Romani to Part II and a minimum of measures under Part III. These usually include the provision of adult education opportunities, measures to ensure the teaching of the history of the community of speakers, and provisions to train teachers to deliver the first two (cf. Halwachs, Schrammel-Leber, \& Klinger 2013:42). Similar statements are made in many of the documents submitted by states in late 2011 in response to the European Commission's call for 'National Strategies for Roma Inclusion 2011-2020'. ${ }^{18}$ To the extent that the Romani language is mentioned, this is usually in connection with affirming the principle of recognition and ensuring support for research and the development of teaching materials. Even where there is a commitment within the framework of the Charter to guarantee education in Romani, implementation is usually found to be lacking, as evidenced by reports issued between 2001-2011 by the Committee of Experts that oversees the Charter (cf. Halwachs et al 2013:44-50). If Romani language classes are offered at all, this is invariably limited to a small number of schools and offered as an option outside of the normal curriculum and with no regular supervision. Some reports even criticise a 'lack of interest' on the part of the authorities and 'poor communication' with the Romani-speaking community.

Interestingly, the Committee of Experts' view on the issues of standardisation underwent a significant paradigm shift. In its 2004 report on Hungary, the 
Committee recommended that standardisation should be pursued at the European level in order to "avoid a purely "national" standardisation which would risk cutting ties with other Roma communities throughout Europe'. In its report on Slovenia from 2007, however, the Committee stated that it has decided to use the term codification rather than standardisation 'in accordance with the suggestion of the European Roma and Traveller Forum'; and in its report on Slovenia, also from 2007, the Committee expressed its support for 'linguistic pluralism in accordance with the best available expertise on the Romany language'. ${ }^{19}$ In fact, the distinction between codification and standardisation was not introduced by the ERTF, but, at the same hearing at the Council of Europe in October 2005, by myself, as was the notion of 'linguistic pluralism' in connection with Romani. ${ }^{20}$ The joint hearing of the Council of Europe's Language Policy Division, the Charter's Expert Committee, and the ERTF thus led to a fundamental change in policy in regard to standardisation and the adoption of an approach which, as Halwachs and colleagues (2013:50) note, parts with common notions of language planning and instead accommodates to the specific sociolinguistic reality of Romani.

Three themes thus emerge from the experience of Romani language policy. First, we witness how the Romani language is acknowledged as a key feature of the culture of the population referred to in the political discourse as Roma/Gypsies. Indeed, in many resolutions, language is regarded as a defining feature of this population and there is explicit recognition of the Romani minority as a linguistic minority, a move away from popular and political conceptualisations of the Romani people as a social grouping or lifestyle. Second, the initiative to grant recognition is taken at the European level. States follow the lead of European policy bodies by adopting similar statements of aims, but they are slow in delivering action and their support is more readily given to research rather than to practical work to extend the use of Romani into the public domain. Arguably, European bodies play a key role in the implementation strategies, too, by delivering a model for a curriculum framework and by providing grants to produce teaching and learning materials and to train teachers. This seems to offer an opportunity for practical initiatives at the European level to enrich national and local provisions for the protection of a minority language. Third, we witness the emergence of a different kind of language policy discourse that departs from conventional language planning strategies and views pluralism of form as enabling domain expansion. This position seeks to override the view put forward by some states, which see the absence of a standard as hindering the promotion of Romani. This change in policy thinking took place at the level of European bodies, in direct response to interaction with researchers and lobbyists. The Romani case may indeed constitute the very first time that policy acknowledges pluralism of dialect and orthography variants in such a way. The background for this paradigm shift is no doubt the absence of territoriality and the proliferation of bottom-up practices of domain expansion, as outlined in the previous section. Altogether, then, we see the gradual emergence of a language 
policy that may be characterised as nonterritorial in its outreach, transnational in its strategic approach, and pluralistic in its practical implementation.

\section{LANGUAGE AS EMPOWERMENT DISCOURSE}

The importance that Romani political associations attribute to the symbolism of language as a token of Romani identity can be witnessed already in the activities of the International Romani Union (IRU), going back to the early 1970s, and its continuous pre-occupation with the theme of language standardization (see Hancock 1991; Courthiade 1992; Kenrick 1996; cf. also Matras 1999, 2013). A more recent illustration is provided by the European Roma and Traveller Forum's (ERTF) draft 'Charter', first released in 2009. In the document, the ERTF defines 'Roma' as follows:

Roma is; who avows oneself to the common historical Indo-Greek origin, who avows oneself to the common language of Romanes, who avows oneself to the common cultural heritage of the Romanipe. $^{21}$

'Indo-Greek origin' appears to refer to the recognition that the core of the Romani language contains, alongside a majority of Indic lexical roots and grammatical inflections, also a strong element of Byzantine Greek origin (cf. Matras 2002). This element is shared by all present-day dialects of Romani, and so it points to a common phase in the early history of the Roma before their dispersion across Europe. Language is a prominent theme on numerous websites of other Romani NGOs as well (see Hughes 2013).

A nice illustration of the importance attributed to the Romani language in circles of political activists is provided by statements of support that accompanied the publication of a Romani-Serbian dictionary by Serbian Romani activist and author Bajram Haliti in August 2011. The quotes were posted online by Haliti himself and circulated widely on Romani electronic mailing lists such as Romano Liloro and Romani Virtual Network. ${ }^{22}$ In addition to affirming the importance of the publication, most of the supporting statements also emphasise the 'authenticity' of Haliti's enterprise. Gheorghe Sarău, coordinator of the Romani language curriculum at the Romanian Education Ministry, writes that Bajram Haliti's dictionary 'contains his personal Roma lingual experience as a journalist, editor from TV and radio, and his great knowledge of Romology'. Romani activist and academic Hristo Kyuchukov from Bulgaria comments how 'the view which B. Haliti presents is the insider view and very few Roma in the world are authors of Romani dictionaries and grammars'; activist and academic Ian Hancock from the US states: 'Much has been written about our Rromani chib, but almost entirely by outsiders. ... native speakers who have compiled dictionaries can be counted on the fingers of one hand. Now Bajram Haliti joins that small but growing number'. ${ }^{23}$ 
The pre-occupation with language is regarded in these statements as an emancipatory political act. 'Authenticity', understood to be a claim to Romani ancestry, is flagged as an indication of the credibility and reliability of an academic enterprise. Language is also adopted as a political identity badge by individuals engaged in campaigns to promote Romani political participation. Influential Romani political activists such as Ian Hancock in the United States, Nicolae Gheorghe in Romania, and Karl Holomek in the Czech Republic ${ }^{24}$ acquired Romani as a foreign language in adulthood after joining activist networks in the 1970s and later. Among the younger generation of activists there are many dozens and perhaps hundreds of individuals who have learned Romani as adults. Examples are Nicolás Jiménez of the organization 'Presencia Gitana' in Spain, Ciprian Necula of the 'Roma Centre for Social Intervention' in Romania, and Daniel Stanko of the Roma Education Fund, from Slovakia. ${ }^{25}$ One might therefore speak cautiously of a Romani language 'revivalist' trend among activists. This has even more far-reaching implications in countries such as Spain, Britain, and Norway, where political activists as well as Pentecostal missionaries of Romani background acquire the language in a setting where Romani is felt to be a heritage language but is no longer spoken by the Romani community (cf. Matras 2010:162-65).

Academic and activist Ian Hancock has been a leading figure in shaping the political discourse that lays a claim to authenticity. Several of his interventions are characterised by attempts to diminish confidence in mainstream scholarship by putting forward an alternative narrative of Romani history. Hancock opens his manifesto publication 'We are the Romani people' (Hancock 2002) by flagging ownership of Romani culture and history (emphasis added):

Although we Romanies have lived in Europe for hundreds of years, almost all popular knowledge about us comes not from socializing with our people at first hand, for we generally live apart from the rest of the population, but from the way we are depicted in stories and songs and in the media. (Hancock 2002:xvii)

Language plays a key role in an attempt to deliver a critique not just of prevailing popular attitudes to Gypsies, but also of mainstream academic historiographical accounts, which bring the Roms in connection with the emigration from India of caste-like groups specialising in itinerant trades and related to the itinerant artisan populations of the dom in India both by name and by social-economic background (see Matras 2002:14-18). Capitalising on the accepted realisation that language provides the principal key to the reconstruction of Romani origins in India, Hancock argues that vocabulary offers an insight into ancient culture and that it allows us not just to refute the hypothesis of a Romani origin in the Indian castes of itinerant artisans, but to replace it by a theory of a supposedly more 'honourable' origin in a military population. Hancock writes:

... almost all of the words [in Romani] having to do with metalwork are Greek, and this leads us to believe that blacksmithing was not a particular skill brought from India, because the basic vocabulary would otherwise be Indian; and so it also tells us that metalworking as a profession was acquired in the Byzantine Empire or in Greece. ... Romani does have a set of words having to do with warfare, 
and those are of Indian origin. The words for 'fight', and 'soldier', and 'sword', and 'spear', and 'plunder' and 'battle-cry' as well as several others have been a part of the language from the very beginning. (Hancock 2002:10)

... the presence of native Indian words in Romani for such concepts as 'king', 'house', 'door', 'sheep', 'pig', 'chicken', 'landowner' (thagar, kher, vudar, bakro, balo, khaxni, raj) and so on point to settled, rather than nomadic, peoples. (Hancock 2002:14)

In this and other publications (Hancock 2000, 2006, 2010a:54-94, 2010b), ${ }^{26}$ Hancock puts forward the claim that an analysis of Romani vocabulary points to an origin in a population of military personnel that was assembled in order to resist the Muslim invasions of India in the eleventh century, and that the Romani language emerged as what Hancock calls a 'military koïné' (for a critique of this idea see Matras 2004). Several of these contributions are part of a discussion context that carries the explicit message - through titles such as 'Danger! Educated Gypsy' (Hancock 2010b) and 'Romani studies through Romani eyes' (Le Bas \& Acton 2010) - that individuals of Romani background can and should put forward their own critical perspective on Romani historiography. A crucial element of the argument is thus the 'authenticity' of the authors themselves. In an online publication, Hancock emphasizes this point very directly:

Surely if groups of individuals who identify themselves as Romanies seek to assert their ethnicity, and to ally themselves with other such groups similarly motivated, then this is entirely their own business, and the non-Romani anthropologists, linguists, sociologists, folklorists and others who have taken upon themselves the role of ethnic police are interfering and presumptuous at best, and are perpetuating paternalistic attitudes. ${ }^{27}$

Hancock's narrative of a Romani military origin has inspired other Romani activists. In his doctoral thesis from 2008, Adrian Marsh, who self-identifies as a Rom, argues that Hancock's idea that Romani emerged as a military koïné is plausible since the related Indic language Urdu obtained its name by association with the Muslim-Turkic military garnisons (Turkish ordu 'military') (Marsh 2008:150). On that basis, he suggests, the ancestors of today's Romani population might be traced to a population of medieval warriors. Marsh, too, authenticates his argument by relating it to his own self-proclaimed ancestry:

As a Romanī historian, it is my intention to outline in this section the historical material that I argue supports the contention that Gypsies can in part can be said to stem from ancestors who fought as warriors with differing military statuses. (Marsh 2008:137)

Marsh goes on to describe a scenario according to which troops who were defeated by the invading Ghaznavid armies in medieval India were split into several groups, some of whom — 'the ancestors of the Romani peoples' (Marsh 2008:150)—were displaced and ended up in Europe.

This theme of a straying population of defeated warriors escaping the Ghaznavid invasions has become widespread in historiographical narratives of Romani activists, many of them posted online but also presented in print and at public conferences and seminars. The following text is attributed to French pro-Romani language activist Marcel Courthiade and has been circulating since 2007: 
They are today 985 year since Mahmud of Ghazni arrived in the Rromani city of Kannauj in India, in 1018 a.D. and meeting no resistance caught all 53,000 inhabitants of the town, in order to lead them as slaves to Kabul and Ghazni where he sold them. He looted all the gold which was in the 10,000 shrines of the city and took also 385 elephants. ${ }^{28}$

Note that the depiction includes a rather detailed narrative that names specific events, dates, and places, none of which can be referenced to any archive documentation that mentions the Roms. Nor is there any plausibility for the assertion that Kannauj in medieval India was a 'Romani city'. This account, too, is 'authenticated' both by Courthiade's self-proclamation of Romani ancestry and his credentials as a language enthusiast and linguist. The same narrative is propagated by Sarah Carmona, self-proclaimed Romani activist and historian from Spain. Attributing her insights to Marcel Courthiade as well as to work by Romani authors and activists Rajko Djurić and Ian Hancock, Carmona reports that structural features of the Romani language prove an origin in the city of Kannauj in Uttar Pradesh. She suggests that Romani shares its pronominal forms, adjectival endings, and its possessive postposition specifically with the Indian dialect of Kannauj (though no actual comparative analysis is provided). She then repeats the claim that the Roms originated in warriors who were captured and expelled in December of 1018 by the invading Muslim armies of Mahmud of Ghazni. ${ }^{29}$

Ronald Lee, a Canadian Romani activist and author of a Romani textbook and dictionary (Lee 2005, 2010), provides a historiographical narrative that tells of conquests, migrations, and captivity, and which relies heavily, much like Hancock's work, on an interpretation of Romani vocabulary. In relation to the formation of the Romani language, Lee concludes:

In the Sultanate of Roum, the language of the group became the military koïné, the only 'native' language they had in common which their parents had spoken under the Ghaznavids plus a gradually adopted battery of Byzantine Greek added to the existing Persian and Armenian borrowings which then became our native language or Romani shib. ${ }^{30}$

Yvonne Slee, a German-born Australian who portrays herself as a Romani leader and maintains close ties with Romani activists, reports on a 'new theory on Romani history' that is supposedly based on ongoing research by Romani activists Ronald Lee and others, including Ian Hancock, Marcel Courthiade, and Adrian Marsh. The 'theory', according to her, suggests this:

\footnotetext{
A group of Indians numbering in the thousands were taken out of India by Mahmud Ghazni in the early 11th century. ... They ended up in Armenia and later in the Seljuk Sultanate of Rom. These proto-Romanies remained in Anatolia for two to three hundred years and during that time they abandoned their military way of life and took up a nomadic lifestyle based on artisan work, trading, animal dealing and entertainment. ${ }^{31}$
}

This narrative has thus received intense circulation within a contained circle of activists. Indirectly, it has even received some degree of institutional acknowledgement through the fact that some of its authors have published their work in a series that claims academic credentials (University of Hertfordshire Press) and 
that some have been invited to lecture their theories at training seminars on Romani history hosted and funded by the Council of Europe. The narrative portrays the Romani people as victims of medieval military campaigns and turns this into an explanatory account of their presence in the European diaspora and of their marginalized status in European society. In attributing a military origin to the Romani population, it challenges the hypothesis of an origin in castes that specialized in mobile services. In this way it depicts the traditional niche that Romani people occupy in European society and the stigmatization that is associated with it as an historical anomaly brought about through social injustice.

In the absence of any historical documentation that can be brought in connection specifically with the Roms to support these ideas, the narrative is presented as anchored in an interpretation of language and especially vocabulary. In this way, activists engage in mimicry of historical linguistic analysis in order to make a political statement. This statement is multi-faceted. It first aims at challenging popular stereotypes of the Romani people as a loose assembly of rootless wanderers who are work-shy and have no sense of history or destiny, and to replace it with an image of a well-defined and proud nation that has been forcefully subjugated. Next, it aims at gaining ground from mainstream scholarship by claiming an 'authentic' Romani voice whose descent-based credentials are sufficient in order to override analyses that are put forward by specialist researchers. Finally, the construction of an alternative narrative and the exchanges within an emerging community of activist-historiographers are perceived as an act of empowerment, where the players assume a collective identity for strategic purposes in the hope that it would lend them authority in the public discourse on Romani politics.

\section{O N C L U S I O N}

Alongside its value in negotiating images, roles, and power relationships, the Romani language has undergone some very practical changes in relation to its domain distribution and consequently in the shapes and forms that communication in Romani can assume. Over the past two decades use of Romani has shifted from being largely confined to oral, face-to-face communication in familiar settings toward increasingly frequent use in written, public, and remote-relay communication. This is supported by new technologies and especially social media, and partly also by institutions that provide infrastructure, expertise, and funding for the creation of printed materials and other media. Language plays a role as an expression of a shared identity, but this is not bound to either territorialisation or the construction of a unified standard. Instead, domain expansion is reconciled with pluralism of structural variants and orthographic representation as well as with personal, individual ownership of form. This is characteristic not just of spontaneous communication in online media, but it also receives institutional acknowledgement in the form of a willingness on the part of facilitators such as the Next Page Foundation and the 
Council of Europe not just to tolerate but also to actively support a policy of pluralism in codification.

To some extent, the Romani experience can be considered to be exceptional. It involves a people with no tradition of literacy and with no geographical territory or form of government, yet surrounded by clear social demarcation boundaries that segregate them from the majority population in most if not all regions in which they reside. However, the advances of domain expansion in Romani during the past two decades draw on a series of key developments that are of a global nature: increased networking and mobility opportunities, the rise of digital communication technology, the role of social media in facilitating virtual communities, the strengthening of transnational forms of governance especially in connection with safeguarding regional and minority rights, and the growing acceptance of multiple identities or 'scapes' in the sense of Appadurai (1992). Against this background, the Romani experience might well set a benchmark for the future development of nonstandard, regional, and minority languages in a globalised world.

\section{N O T E S}

\footnotetext{
*The paper is an outcome of a collaborative research project on 'The Role of Language in the Transnational Formation of Romani Identity (RomIdent)' which was financially supported by the HERA Joint Research Programme (www.heranet.info) which is cofunded by AHRC, AKA, DASTI, ETF, FNR, FWF, HAZU, IRCHSS, MHEST, NWO, RANNIS, RCN, VR, and The European Community FP7 2007-2013, under the Socio-economic Sciences and Humanities programme (2010-2013).

${ }^{1}$ See http://www.npage.org/article40.html; accessed October 20, 2013.

${ }^{2}$ http://romani.uni-graz.at/romlex/

${ }^{3}$ http://sverigesradio.se/sida/default.aspx?programid=2122; accessed October 29, 2013.

${ }^{4}$ http://radio-romani-mahalla.weebly.com/

${ }^{5}$ Romanes is the usual Romani name for the Romani language.

${ }^{6}$ European Commission: Anti-Discrimination Law Review, 6/7(2008), p. 44; online: http://www. migpolgroup.com/public/docs/145.EuropeanAnti-discLawReview_6_7_en_11.08.pdf.

7'Breaking barriers: Romani women and access to public health care', 2003, p. 10.

${ }^{8}$ Council of Europe, Training Modules for Teachers in the History, Culture and Language of the Roma, Strasbourg, 2003.

${ }^{9}$ Rus, Calin (2004). Report on 'The training of Roma school mediators and assistants'. Strasbourg: Council of Europe.

${ }^{10}$ Council of Europe, European Charter for Regional or Minority Languages, Committee of Experts, MIN-LANG (2006) 3, Strasbourg, 6 March 2006. Report on Hearing with the Language Policy Division (Council of Europe), 5 October 2005, p. 8. Online: http://www.coe.int/t/dg4/education/ minlang/publications/ReportERTFHearing_en.pdf.

${ }^{11}$ Council of Europe, European Charter for Regional or Minority Languages, Committee of Experts, MIN-LANG (2006) 3, Strasbourg, 6 March 2006. Report on Hearing with the Language Policy Division (Council of Europe), 5 October 2005, p. 10. Online: http://www.coe.int/t/dg4/education/ minlang/publications/ReportERTFHearing_en.pdf.

${ }^{12}$ Council of Europe, European Charter for Regional or Minority Languages, Committee of Experts, MIN-LANG (2006) 3, Strasbourg, 6 March 2006. Report on Hearing with the Language Policy Division (Council of Europe), 5 October 2005, pp. 13-14. Online: http://www.coe.int/t/dg4/education/minlang/ publications/ReportERTFHearing_en.pdf.
} 


\section{YARON MATRAS}

${ }^{13}$ Council of Europe, Language Policy Division, A Curriculum Framework for Romani, developed in co-operation with the European Roma and Travellers Forum, 2008. Online: http://www.coe.int/t/dg4/ linguistic/Source/Rom_CuFrRomani2008_EN.pdf.

${ }^{14}$ www.romaninet.com

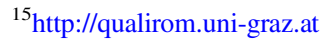

${ }^{16}$ European Parliament, Resolution of 9 March 2011 on the EU Strategy on Roma Inclusion, par. 4.

${ }^{17}$ European Commission against Racism and Intolerance, General Policy Recommendation No. 13

'On combatting anti-Gypsyism and discrimination against Roma', 24 June 2011, section 4(n).

${ }^{18} \mathrm{http}: / /$ ec.europa.eu/justice/discrimination/roma/national-strategies/; accessed February 2012.

${ }^{19}$ All quotes and citations from the Committee reports are from Halwachs et al. (2013:50).

${ }^{20}$ see http://www.coe.int/t/dg4/education/minlang/publications/ReportERTFHearing_en.pdf; and Matras (2005a, 2005b).

${ }^{21}$ Charter of the European Roma and Traveller Forum (ERTF), Art. 1. Online: http://www.ertf.org/ images/stories/documents/ERTF_Charter_EN.pdf.

${ }^{22} \mathrm{http}: / / \mathrm{www} \cdot$ romabuzzmonitor.net/first-orthographic-dictionary-of-roma-language-with-grammarand-orthographic-adviser-by-author-bajram-haliti/; accessed August 1, 2011.

${ }^{23} \mathrm{http}$ ://www.romabuzzmonitor.net/first-orthographic-dictionary-of-roma-language-with-grammarand-orthographic-adviser-by-author-bajram-haliti/; accessed August 1, 2011.

${ }^{24}$ On the latter, information obtained from Jana Horváthová, p.c. October 3, 2013.

${ }^{25}$ p.c., October 2, 2013

${ }^{26}$ The University of Hertfordshire Press has played a key role in the dissemination of texts on Romani issues written by activist-scholars such as Ian Hancock, Thomas Acton, and Ronald Lee.

${ }^{27} \mathrm{http}: / /$ radoc.net:8088/RADOC-9-IDENT-1.htm; accessed August 1, 2004.

${ }^{28}$ Posting by Saimir Mile on Roma_India@yahoogroups.com, December 20, 2007.

${ }^{29} \mathrm{http}$ ://baxtalo.wordpress.com/nuevas-perspectivas-sobre-historia-gitana; accessed March 3, 2013.

${ }^{30} \mathrm{~A}$ new look at our Romani origins and diaspora, by Ronald Lee, 2009. Online: http://kopachi.com/ articles/a-new-look-at-our-romani-origins-and-diaspora-by-ronald-lee/; accessed November 10, 2013.

${ }^{31} \mathrm{http}: / /$ www.rromaniconnect.org/Romanihistory.html; accessed October 28, 2013.

\section{R E F E R E N C E S}

Anderson, Benedict (1983). Imagined communities: Reflections on the origin and spread of nationalism. London: Verso.

Androutsopoulos, Jannis (2013). Code-switching in computer-mediated communication. In Susan C. Herring, Dieter Stein, \& Tuija Virtanen (eds.), Pragmatics of computer-mediated communication, 667-94. Berlin: De Gruyter Mouton.

Appadurai, Arjun (1992). Global ethnoscapes: Notes and queries for a transnational anthropology. In R. G. Fox (ed.), Interventions: Anthropologies of the present, 191-210. Santa Fe, NM: School of American Research.

Aydıngün, Ayșegü, \& İsmail Aydıngün (2004). The role of language in the formation of Turkish national identity and turkishness. Nationalism and Ethnic Politics 10:415-32.

Baker, Colin (1992). Attitudes and language. Clevedon: Multilingual Matters.

Blommaert, Jan (2005). Discourse: A critical introduction. Cambridge: Cambridge University Press. Courthiade, Marcel (1992). Research and action group on Romani linguistics. Interface 8:4-11.

Crowley, Tony (2003). Standard English and the politics of language. London: Palgrave Macmillan. (2007). Language endangerment, war and peace in Ireland and Northern Ireland. In Alexandre Duchêne \& Monica Heller (eds.), Discourses of endangerment, 149-68. London: Continuum.

Eckert, Penelope (2003). Sociolinguistic and authenticity: An elephant in the room. Journal of Sociolinguistics 7:392-431.

Edwards, John (2006). Language and identity. Cambridge: Cambridge University Press. 


\section{TRANSNATIONAL POLICY AND ‘AUTHENTICITY’ DISCOURSES}

Fairclough, Norman (1989). Language and power. Harlow: Longman.

Fishman, Joshua A.; Charles A. Ferguson; \& Jyotirindra Dasgupta (eds.) (1968). Language problems in developing nations. New York: Wiley.

Fought Carmen (2006). Language and ethnicity. Cambridge: Cambridge University Press.

Giles, Howard, \& Patricia Johnson (1987). Ethnolinguistic identity theory: A social psychological approach to language maintenance. International Journal of the Sociology of Language 68:69-99.

Halwachs, Dieter W. (2011). Romani, language planning and the media. Current Issues in Language Planning 12(3):381-401.

(2012). Linguistic diversity, dominated languages and the internet: The case of Romani. In Anastasia Parshakova (ed.), Linguistic and cultural diversity in cyberspace: Proceedings of the 2nd International Conference, 272-81. Paris: UNESCO.

; Barbara Schrammel-Leber; \& Simone A. Klinger (2013). Romani, education, segregation and the European Charter for Regional and Minority Languages. Graz: Grazer Romani Publikationen.

Hancock, Ian F. (1991). Vlax phonological divergence from common Romani: Implications for standardization and orthography. In William G. Boltz \& Michael C. Shapiro (eds.), Studies in the historical phonology of Asian languages, 102-18. Amsterdam: John Benjamins.

(2000). The emergence of Romani as a koïné outside of India. In Donald Kenrick \& Thomas Acton (eds.), Scholarship and the Gypsy struggle: Commitment in Romani studies, 1-13. Hatfield: University of Hertfordshire Press.

(2002). We are the Romani people. Ame sam e Rromane džene. Hatfield: University of Hertfordshire Press.

(2006). On Romany origins and identity: Questions for discussion. In Adrian Marsh \& Elin Strand (eds.), Gypsies and the problem of identities: Contextual, constructed and contested, 69-92. Istanbul: Swedish Research Institute.

(2010a). Danger! Educated Gypsy: Selected essays. Hatfield: University of Hertfordshire Press.

(2010b). Mind the doors! The contribution of linguistics. In Le Bas \& Acton, 5-25.

Herring, Susan C. (2008). Virtual community. In Lisa M. Given (ed.), Encyclopedia of qualitative research methods, 920-21. Los Angeles, CA: Sage.

Hughes, Philippa (2013). Language and the representation of Romani identity on websites. RomIdent Working Papers 23. Online: http://romani.humanities.manchester.ac.uk/virtuallibrary/librarydb// web/files/pdfs/378/Paper23.pdf.

Jaffe, Alexandra (1999). Ideologies in action: Language politics on Corsica. Berlin: Mouton de Gruyter.

Joseph, John E. (2004). Language and identity: National, ethnic, religious. New York: Palgrave Macmillan.

Kaplan, Robert B., \& Richard B. Baldauf (1997). Language planning from practice to theory. Clevedon: Multilingual Matters.

Kenrick, Donald (1996). Romani literacy at the crossroads. International Journal of the Sociology of language 119:109-23.

Kuzar, Rom (2001). Hebrew and Zionism: A discourse analytic cultural study. Berlin: Mouton de Gruyter.

Le Bas, Damien, \& Thomas Acton (eds.) (2010). All change! Romani studies through Romani eyes. Hatfield: University of Hertfordshire Press.

Lee, Ronald (2005). Learn Romani: Das-duma Rromanes. Hatfield: University of Hertfordshire Press. (2010). Romani dictionary: Kalderash-English. Hatfield: University of Hertfordshire Press.

Leggio, Danielle V. (2013). Lace avilen ko radio: Romani language and identity on the internet. Manchester: University of Manchester dissertation.

— \& Yaron Matras (2013). Social networks as centres of language codification: Romani on YouTube. RomIdent Working Papers 32. Online: http://romani.humanities.manchester.ac.uk/virtual library/librarydb//web/files/pdfs/388/Paper32.pdf.

Marsh, Adrian R. N. (2008). 'No promised land': History, historiography and the origins of the Gypsies. London: University of Greenwich dissertation. 


\section{YARON MATRAS}

Matras, Yaron (1999). Writing Romani: The pragmatics of codification in a stateless language. Applied Linguistics 20:481-502.

(2002). Romani: A linguistic introduction. Cambridge: Cambridge University Press.

(2004). A conflict of paradigms. Review article of Zoltan Barany, The East-European Gypsies; and Ian Hancock, We are the Romani people. Romani Studies 5(14-2):193-209.

(2005a). The status of Romani in Europe. Report commissioned by the Council of Europe's Language Policy Division, October 2005.

(2005b). The future of Romani: Toward a policy of linguistic pluralism. Roma Rights Quarterly $1: 31-44$

(2010). Romani in Britain: The afterlife of a language. Edinburgh: Edinburgh University Press.

(2013). Scholarship and the politics of Romani identity: Strategic and conceptual issues. European Yearbook of Minority Issues 10:209-45.

, \& Gertrud Reershemius (1991). Standardization beyond the state: The case of Yiddish, Kurdish and Romani. In Utta von Gleich \& Ekkehardt Wolff (eds.), Standardization of national languages, 103-23. Hamburg: UNESCO-Institut für Pädagogik.

Milroy, James (2001). Language ideologies and the consequences of standardization. Journal of Sociolinguistics 5:530-55.

Rajah-Carrim, Aaliya (2009). Use and standardisation of Mauritian Creole in electronically mediated communication. Journal of Computer-Mediated Communication 14:484-508.

Rheingold, Howard (1993). The virtual community: Homesteading on the electronic frontier. New York: Rutledge.

Skutnabb-Kangas, Tove, \& Robert Phillipson (eds.) (1994). Linguistic human rights: Overcoming linguistic discrimination. Berlin: Mouton de Gruyter.

Spolsky, Bernard (2003). Language policy. Cambridge: Cambridge University Press.

Wright, Sue (2004). Language policy and language planning: From nationalism to globalisation. New York: Palgrave McMillan.

(Received 18 January 2014; revision received 18 August 2014; accepted 30 August 2014; final revision received 22 September 2014) 